\title{
Radioactive potential of zirconium-dioxide used for dental applications
}

\author{
Bavbek, Andac Barkin ; Òzcan, Mutlu ; Eskitascioglu, Gürcan
}

\begin{abstract}
PURPOSE The purpose of this study was to investigate the possible radioactive potential of zirconium dioxide $(\mathrm{ZrO} 2)$ dental ceramics. Such information is necessary since they became an integral part of routine prosthetic rehabilitations and devoid of scientific information about their radioactivity creates some concern in the dental community. METHODS Four different types of commercial ZrO2 ceramics, namely Lava, Cercon, ICE Zirkon, and Everest Bio ZS were investigated before and after the sintering process. Sintering temperatures were applied according to each manufacturer's instructions. The compositions of the presintered and sintered specimens were analyzed using $\mathrm{x}$-Ray Fluorescence Spectrometer (XRF). Concentrations of the elements and compounds were also measured by this method. Determination of radioactivity continued with Gamma-spectrometry measurements and Gross alpha/Beta analyses. RESULTS The activity of gamma and Gross alpha/beta was below minimum detection limits (MDL) for presintered and sintered $\mathrm{ZrO} 2$. The MDLs of gross alpha/beta counting system were $0.02 \mathrm{~Bq} / \mathrm{g}$ and $0.01 \mathrm{~Bq} / \mathrm{g}$ for alpha and beta radioactivity, respectively. The sintering process played only a minor role in the composition of the compounds. CONCLUSIONS Radioactivity of the ZrO2 ceramics studied showed negligible radionuclide activity that can be considered lower than many hazardous radioactive appliances in our environment.
\end{abstract}

DOI: https://doi.org/10.5301/JABFM.2012.9341

Posted at the Zurich Open Repository and Archive, University of Zurich ZORA URL: https://doi.org/10.5167/uzh-100661

Journal Article

Accepted Version

Originally published at:

Bavbek, Andac Barkin; Özcan, Mutlu; Eskitascioglu, Gürcan (2014). Radioactive potential of zirconium-dioxide used for dental applications. Journal of Applied Biomaterials Biomechanics, 12(1):35-40.

DOI: https://doi.org/10.5301/JABFM.2012.9341 


\section{Radioactive Potential of Zirconium-dioxide Used for Dental Applications}

\section{Andac Barkin Bavbek ${ }^{1}$, Mutlu Özcan ${ }^{2}$, Gurcan Eskitascioglu',}

1 Faculty of Dentistry, Department of Prosthodontics, University of Yuzuncu Yil, Van, Turkey

2 Dental Materials Unit, Center for Dental and Oral Medicine, Clinic for Fixed and Removable Prosthodontics and Dental Materials Science, University of Zürich, Zürich, Switzerland

Short title: Radioactive potential of zirconia

${ }^{*}$ Corresponding author:

Dr. Andaç Barkın Bavbek

University of Yuzuncu Yil

Faculty of Dentistry

Department of Prosthodontics

65080 Kampus

Van, Turkey

Tel: +90 432-2251764; fax: +90-432-2251747

E-mail: bavbekab@yahoo.com 


\begin{abstract}
Objectives. The purpose of this study was to investigate the possible radioactive potential of zirconium dioxide $\left(\mathrm{ZrO}_{2}\right)$ dental ceramics. Such information is necessary since they became an integral part of routine prosthetic rehabilitations and devoid of scientific information about their radioactivity creates some concern in the dental community.
\end{abstract}

Methods. Four different types of commercial $\mathrm{ZrO}_{2}$ ceramics, namely Lava, Cercon, ICE Zirkon and Everest Bio ZS were investigated before and after sintering process. Sintering temperatures were applied according to each manufacturer's instructions. The compositions of the presintered and sintered specimens were analyzed using X-Ray Fluorescence Spectrometer (XRF). Also concentrations of the elements and compounds were measured by this method. Determination of radioactivity was continued with Gamma-spectrometry measurements and Gross alpha/Beta analyses.

Results. For a 24 hour counting time, no measurable level of gamma and gross alpha/beta emitting radionuclide activity. The activity of gamma and Gross alpha/beta below minimum detection limits (MDL) for presintered and sintered ZrO2. The MDLs of gross alpha/beta counting system were $0.02 \mathrm{~Bq} / \mathrm{g}$ and $0.01 \mathrm{~Bq} / \mathrm{g}$ for alpha and beta, radioactivity respectively. Sintering process played only a minor role at the composition of the compounds.

Significance. Radioactivity of the studied $\mathrm{ZrO}_{2}$ ceramics showed negligible radionuclide activity that can be considered lower than many hazardous radioactive appliances in our environment.

Keywords: Radioactivity; XRF; Gamma Spectroscopy; Zirconia 


\section{Introduction}

Zirconium, which means golden in colour, is the $18^{\text {th }}$ most abounded element in the earth [1]. Zirconium does not occur in nature in pure state and is refined from naturally occurring ores. It usually contains trace amounts of other elements depending upon the source of the original ore. The geological process that forms zirconium minerals such as zirconium silicate $\left(\mathrm{ZrSiO}_{4}\right)$ and zirconium dioxide $\left(\mathrm{ZrO}_{2}\right)$ leads to incorporation of some radionuclides into crystal structure [2]. Zirconia, is a polymorphic oxide that exist in three different crystal structures as monoclinic, tetragonal and cubic [3-5]. In particular, $\mathrm{ZrO}_{2}$ typically contains trace amounts of radionuclides such as radium and thorium and also uranium [6-8]. These radionuclides generate alpha, beta and gamma radiations [9]. According to safety reports about $\mathrm{ZrO}_{2}$, radioactive impurities need to be taken into account due these radionuclides especially when they are used in industrial applications and medical areas [2].

The primary application of the $\mathrm{ZrO}_{2}$ as a biomaterial in medicine is attributed to hip replacements in 1960s [10]. The success of the biomaterial in the body depends on mechanical properties and biocompatibility. Some stabilizing oxides such as $\mathrm{CaO}, \mathrm{MgO}, \mathrm{CeO}_{2}$ and $\mathrm{Y}_{2} \mathrm{O}_{3}$ are supplemented to the structure in order to withstand the phase transformations $[5,10]$. The positive experience and studies of $\mathrm{ZrO}_{2}$ that achieved by orthopedics, navigates the

dentist to inspire an alternative treatment strategy in odontology [1,4]. $\mathrm{ZrO}_{2}$-based technology in dentistry is subjected by manufacturers behind requirements of the scientist for $\mathrm{ZrO}_{2}$ ceramics in biomechanics and cosmetics are gained. Today the use of $\mathrm{ZrO}_{2}$ restorations is increasing due to the developments in CAD-CAM systems [4]. Partially sintered (presintered) $\mathrm{ZrO}_{2}$ ceramic blocks, that sintered at about $950^{\circ} \mathrm{C}$, make the material easier to be machined. The machined products are sintered again therefore excellent mechanical structure with dentin-like appearance may occur with high success [8,11]. However, $\mathrm{ZrO}_{2}$ ceramics reveals a considerable higher level of radioactivity compared with other dental ceramics [9]. 
In 1970s some additives are presented in dental ceramics to mimic fluorescent characteristic of human dentin. These additives increased the potential of radioactivity of dental restorations due to uranium, radium and thorium chains. The international community has taken steps to minimize the use of naturally occurring radioactive materials. The International Standards Organization and the American Dental Association, in conjunction with the American National Standards Institute, specifies in their standards and guidelines for acceptance that radioactive substances shall not be added intentionally to the porcelain formulations [12]. Uranium radionuclide is presented in dental ceramics until ADA/ANSI Specifications No. 69 (American National Standards Institute/American Dental Association, 1991) is accepted [13]. Later, the use of some additives, which increase potential of radioactivity, is restricted in dental ceramics according to ISO standards (ISO 6872 and 4824) [9]. However, $\mathrm{ZrO}_{2}$ ceramics arouse some researchers to suspect due the possible uranium, radium and thorium chains $[6,14]$. These radionuclides may be present at minimum levels or different isotopes of another element and may be radioactive. In the examination report of Rieger [15], an activity $\mathrm{U}^{238}$ of $0.003 \mathrm{~Bq} / \mathrm{g}$ records for $\mathrm{ZrO}_{2}$ ceramics. A small dose of radiation caused by radionuclides always occurs around the environment. The human body is exposed to radiation from the Sun, ground, electronic devices and also naturally occurring radionuclides in our body tissues [20]. If the dose exceeds the limits it becomes harmful for the health, finally mutagenic or transforming effects may be caused in some tissues [7]. The patient, rehabilitated with suspicious ceramic material, is prone to contaminate with radionuclides. In fact a dental technician may be contaminated by this ceramic in presintered form with dust exposure during milling process. Nevertheless, there is a paucity of information related to radioactivity risk in dental applications of $\mathrm{ZrO}_{2}$ ceramics. Therefore, the objective of this study was to investigate the radioactive potential of $\mathrm{ZrO}_{2}$ both in laboratory and clinic side as presintered and sintered form since it started to be widely used as a new biomaterial in dental appliances. 


\section{Material and methods}

\subsection{Specimens}

Four different types of commercial $\mathrm{ZrO}_{2}$ ceramics were obtained from the manufacturers and investigated (Table 1). The specimens, (diameter: $10 \mathrm{~mm}$, thickness: $2 \mathrm{~mm}$ ), were computer projected from a specific programme. The specimens were cleaned in an ultrasonic bath in acetone for 10 minutes.

\subsection{Chemical analysis}

Prior to performing experiments, the composition and concentration of the $\mathrm{ZrO}_{2}$ samples was analysed by PANalytical AXIOS Wavelength Dispersive X-Ray Fluorescence Spectrometer (WDXRF) with IQ+ software programme for elemental analyses. The power capacity of the system is $4 \mathrm{~kW}$ with maximum $160 \mathrm{~mA}$ current. XRF is based on the principle that individual atoms, when excited by an external energy source, emit X-ray photons of a characteristic energy or wavelength. By counting the number of photons of energy emitted from a sample, the elements present may be identified and quantified.

\subsection{Radioactivity analysis}

Two common units to measure the activity of a substance are the curie $(\mathrm{Ci})$ and becquerel (Bq). A curie is a unit of measure of the rate of radioactive decay equal to $3.7 \times 10$ disintegrations 10 per second. This is approximately equivalent to the number of disintegrations that one gram of radium-226 will undergo in one second. A becquerel is a more fundamental unit of the measure of radioactive decay that is equal to 1 disintegration per second. Currently, the curie is more widely used in the United States, but usage of the becquerel can be expected to broaden as the metric system slowly comes into wider use. The conversion between curies and becquerels is shown below:

1 curie $=3.7 \times 10$ becquerels 
In the radioactivity analyses specimens were observed whether they have any radioactive behaviour. Determination of radioactivity was completed in two stages:

\subsubsection{Gamma-spectrometry measurements}

Gamma spectrometry technique that is a highly suitable counting technique for non-destructive analysis is used to measure the gamma radioactivity. Specimens were positioned on the high purity Germanium (HPGe) detector. Powder samples are put into cylindrical containers of the detector before measurement process started.

\subsubsection{Gross alpha/Beta analyses}

Gross alpha/beta counting system was used to measure the alpha and beta radioactivity. All samples were counted automatically low-level Alfa/Beta counted system (PIC WEP 9550).

\section{Results}

Elemental analyses evaluated by XRF spectrometer are presented in Table 2. The analyses showed that the difference between the presintered and sintered forms were not significant. Minimal changes occurred in all samples after the points of the main percentage. However, a differentiation in compounds was not expressed. Although XRF analyses showed compositions of the specimens with high sensitivity, an element or compound that presents below the $0.5 \%$ of total composition cannot be supplied due to limitations of the spectrophotometer. In Figs 1a-b Everest Bio ZS samples were randomly represented as a sample graph since XRF measurement of $\mathrm{ZrO}_{2}$ samples in all groups showed similar trends before and after the sintering process.

For a 24 hour counting time, no measurable level of gamma emitting radionuclide activity was found. The activity of gamma and gross/alpha did not exceed the minimum detection limits (MDL). The MDLs of gross alpha/beta counting system were $0.02 \mathrm{~Bq} / \mathrm{g}$ and $0.01 \mathrm{~Bq} / \mathrm{g}$ for alpha and beta radioactivity, respectively. 


\section{Discussion}

Both medical and dental professions are concerned about the safety of dental treatment and any potential health risks that might be associated with the materials used to restore the teeth [21]. Akagawa et al., presented that $\mathrm{ZrO}_{2}$ ceramic is an inert material [22]. If a material is accepted as biocompatible, this product should not be responsible for inflammatory reactions neither to provoke allergic, immune, toxic, mutagen, or carcinogenic reactions [1,6]. Although a few studies evaluated the $\mathrm{ZrO}_{2}$ ceramics for their radioactive potential, Veronese et al. [13] generalized that if a patient is rehabilitated with any prosthetic restoration, the risk of radionuclide activity may be 10 times greater than other healthful members of the population. Some reviews about $\mathrm{ZrO}_{2}$ ceramics did not deal with the potential radioactivity risk $[4,10]$. However, Schmalz et al., stated that radioactivity concentration of modern $\mathrm{ZrO}_{2}$ ceramics is below the normal threshold level [9]. Similarly, measurable level of some radionuclides could not be determined in this present study. The activity of gamma and gross/alpha were below the minimum detection limits (MDL) for presintered and sintered ZrO2. The Gross alpha/beta counting system's MDLs were 0.02Bq/g and $0.01 \mathrm{~Bq} / \mathrm{g}$ for alpha and beta radioactivity, respectively. According to manufacturers'recommendation the radioactivity of Z-Blank is measured at value of $0.005 \mathrm{~Bq} / \mathrm{g}$ that is much lower than the maximum value of $1 \mathrm{~Bq} / \mathrm{g}$ permitted by ISO 6872.

When the $\mathrm{ZrO}_{2}$ ceramic, which posses high concentration of hazardous radionuclides, is used in a restoration, alpha particles may only play a minor role for oral tissues because alpha particles have a maximum range of $30 \mu \mathrm{m}$ in tissues and they may already be absorbed by the saliva and plaque covering the restoration before reaching the radiosensitive cells in the basal layer of the oral mucosa [9]. The beta and gamma particles may have a much higher range of absorption in the tissues. Hence, a greater volume of the body's tissues is exposed to beta and gamma than with alpha particles [14]. Gamma particles induces dose to all the tissues of the oral mucosa depending on the energy of the gamma ray photons [19]. On the other hand, these 
particles are also of extremely low level in contaminations and very hard to measure. Covacci et al. [7] investigated $10 \mathrm{~T}_{1 / 2}$ cells due to the possible mutagenic and transforming effects of purified and unpurified $\mathrm{ZrO}_{2}$ ceramics. Cells were used between $11^{\text {th }}$ and $18^{\text {th }}$ passage and subcultivation of stock cultures was performed before they reached confluence. Samples did not show mutagenic and transforming effects on $10 \mathrm{~T}_{1 / 2}$ cells.

Dental materials are ground and polished in the patients' mouth, sometimes with unintentional damage to the oral mucosa thus resulting in more exposure to the very dental material used in the restorations. Also, a possibility that the patient is swallowing radioactive particles due to teeth grinding or dental treatment needs to be addressed in future studies. Possible inhalation of radioactive compounds by patients, technicians and dentists has to be taken into account when examining the biocompatibility of these dental materials in future studies.

Willman pointed out that manufacturing process of $\mathrm{ZrO}_{2}$ ceramics is an important step for human health due to possible radioactive impurities that is not effectively eliminated from the compound [16]. Present study evaluated the specimens not only at the end of the process but also prior to sintering. Developments in recent years proves that $\mathrm{ZrO}_{2}$ ceramics are suitable for CAD/CAM processes as in all three conditions unsintered, partly sintered (pre-sintered) and sintered stages. The pre-sintered $\mathrm{ZrO}_{2}$ blanks have a chalk consistency and they are easily workable by the dental laboratories with any kind of CAD/CAM devices to produce crowns and FDPs. Due to the easier workability and faster machining, the use of pre-sintered blanks is predominant today. After a final sintering process, some alterations in density, grain size, amount of cubic phase in the $\mathrm{ZrO}_{2}$ body occur but at the same time ultimate strength is achieved [17]. This alteration in sintering process is not only a physical but also a chemical reaction. Some ions in $\mathrm{ZrO}_{2}$ ceramic appear to concentrate within the large grains after sintering [18]. If only sintered or pre-sintered specimens were analyzed in the present study we would have agreed that they were the same materials before the experiments. However, the XRF results suggested 
that chemical composition of the samples did not vary by sintering process. For this reason both presintered and sintered samples presented radioactivity below the threshold levels.

\section{Conclusions}

From this study, the following could be concluded:

1. The activity of gamma and Gross alpha/beta found below the minimum detection limits (MDL) for the $\mathrm{ZrO}_{2}$ ceramics studies.

2. Radioactivity levels and XRF measurements did not show any difference between presintered and sintered $\mathrm{ZrO}_{2}$ ceramics.

\section{Acknowledgements}

The authors thank Prof. H. Alkumru for his assistance in supplying the materials used in this study and Dr. A. Zararsiz, A. Parmaksiz and H.I. KAYA for radioactivity and XRF analysis. 


\section{References}

[1] Hisbergues M, Vendeville S, Vendeville P. Zirconia: Established facts and perspectives for a biomaterial in dental implantology. J Biomed Mater Res Part B Appl Biomater 2009;88:519-29.

[2] Radiation protection and norm residue management in the zircon and zirconia industries. Safety reports series no: 51, International Atomic Energy Agency, Vienna 2007.

[3] Sickafus KE, Matzke HJ, Hartman TH, Yasuda K, Valdez JA, Chodak III P, Nastasi M, Verrall RA. Radiation damage effects in zirconia. J Nucl Mater 1999;274:66-7.

[4] Conrad HJ, Seong W-J, Pesun IJ. Current ceramic materials and systems with clinical recommendations: A systematic review. J Prosthet Dent 2007;98:389-404.

[5] Lazar DRR, Bottino MC, Özcan M, Valandro LF, Amaral R, Ussui V, Bressiani AHA. Y-TZP ceramic processing from coprecipitated powders: A comprarative study with three commercial dental ceramics. Dent Mater 2008;24:1676-85.

[6] Piconi C, Maccauro G. Zirconia as a ceramic biomaterial. Biomaterials 199; 20:1-25.

[7] Covacci V, Bruzzese N, Maccauro G, Andreassi C, Ricci GA, Piconi C, Marmo E, Burger W, Cittadini A. In vitro evaluation of the mutagenic and carcinogenic power of high purity zirconia ceramic. Biomaterials 1999;20:371-76.

[8] Liang X, Qiu Y, Zhou S, Hu X, Yu G, Deng X. Preparation and properties of dental zirconia ceramics. J Univ Sci Technol Beijing 2008;15:764-68.

[9] Schmalz G, Arenholt-Binslev D. Biocompatibility of Dental Materials; Urban \& Fischer (Elsevier), 2008, pp. 182-84.

[10] Manicone PF, lommetti PR, Raffaelli L. An overview of zirconia ceramics: Basic properties and clinical applications. J Dent 2007;35:819-26.

[11] Christensen GJ. Porselain-fused-to-metal versus zirconia-based ceramic restorations. JADA 2009;140:1036-39.

[12] Anusavice KJ. Degradability of dental ceramics. Adv Dent Res 1992;6:82-89. 
[13] Veronese I, Guzzi G, Giussani A, Cantone MC, Ripati D. Determination of dose rates from narural radionuclides in dental materials. J Environ Radioactivity 2006;91:15-26.

[14] Porstendörfer J, Reineking A, Willert HG. Radiation risk estimation based on activity measurement of zirconium oxide implants. J Biomed Mater Res 1996;32:663-67.

[15] Rieger W. Studies of Biocompatibility of $\mathrm{ZrO}_{2}$ and $\mathrm{Al}_{2} \mathrm{O}_{3}$ ceramics. Contribution 6th Biomaterial Symposium Göttingen, 1994.

[16] Willmann G. Review: Ceramics for total hip replacement- What a surgeon should know. Orthopedics 1998;21:173-77.

[17] Chevalier J. What future for zirconia as a biomaterial? Biomaterials 2006;27:535-43.

[18] Kelly JR, Denry I. Stabilized zirconia as a structural ceramic: An overview. Dent Mater 2008;24:289-98.

[19] Papastefanou C, Vitsenzos S, Garefis P. Uranium in dental porcelain powders and dose induced in oral mucosa. Radiation protection dosimetry. 1987;19:49-53.

[20] Lindell B. Radiation and health. Bulletin of World Health Organization 1987;65:139-48.

[21] Mackert JR. Side-effects of dental ceramics. Adv Dent Res 1992;6:90-93.

[22] Akagawa Y, Hosokawa R, Sato Y, Kamayama K. Comparison between freestanding and tooth-connected partially stabilized zirconia implants after two years' function in monkeys: a clinical and histologic study. J Prosthet Dent 1998;80:551-58. 


\section{Captions to the legends:}

Tables:

Table 1. The codes, brands, sinterization process and manufactures of the ceramics used for the experiments. Sintering process of $\mathrm{L}-2, \mathrm{C}-2, \mathrm{I}-2$, and $\mathrm{K}-2$ brands were performed according to manufacturer recommendations at $1500^{\circ} \mathrm{C} / 11 \mathrm{~h}, 1350^{\circ} \mathrm{C} / 6 \mathrm{~h}, 1500^{\circ} \mathrm{C} / 5 \mathrm{~h}$, and $1450^{\circ} \mathrm{C} / 10 \mathrm{~h}$, respectively.

Table 2. XRF analyses of all the zirconia specimens and percentages of the major compounds. These analyses were performed to investigate the degradation of the major compounds which were higher $0.5 \%$ of total composition. Ratios of the compounds of specimens in presintered and sintered forms did not show significant alteration.

\section{Figures:}

Figs. 1a-b. Representative X-Ray Fluorescence Spectrometer (XRF) analysis for the Zr and Hf elements of Everest Bio $\mathrm{ZS} \mathrm{ZrO}_{2}$ ceramic specimen in a) presintered b) sintered form. The peaks are the characteristic X-rays of the elements in the specimens. X-axis shows the energy levels. According to graphics there is no significant difference between two forms. In all groups and all forms no difference was detected where K-1 and K-2 specimens were randomly selected to evaluate their energy levels. 


\section{Tables:}

\begin{tabular}{|c|c|c|c|}
\hline Code & Brand & Sinterization & Manufacturer \\
\hline $\mathrm{L}-1$ & Lava & Sintered & $\begin{array}{c}\text { 3M ESPE, St. } \\
\text { Paul, Minnesota, } \\
\text { USA }\end{array}$ \\
\hline L-2 & Lava & Pre-sintered & $\begin{array}{c}\text { 3M ESPE, St. } \\
\text { Paul, Minnesota, } \\
\text { USA }\end{array}$ \\
\hline C-1 & Cercon & Sintered & $\begin{array}{c}\text { Dentsply } \\
\text { Ceramco, York, } \\
\text { Pennsylvania, } \\
\text { USA }\end{array}$ \\
\hline C-2 & Cercon & Pre-sintered & $\begin{array}{c}\text { Dentsply } \\
\text { Ceramco, York, } \\
\text { Pennsylvania, } \\
\text { USA }\end{array}$ \\
\hline I-1 & ICE Zirkon & Sintered & $\begin{array}{c}\text { Zirkonzahn, } \\
\text { GmbH, Bruneck, } \\
\text { Italy }\end{array}$ \\
\hline I-2 & ICE Zirkon & Pre-sintered & $\begin{array}{c}\text { Zirkonzahn, } \\
\text { GmbH, Bruneck, } \\
\text { Italy }\end{array}$ \\
\hline $\mathrm{K}-1$ & Everest Bio ZS & Sintered & $\begin{array}{l}\text { KaVo Dental, } \\
\text { Lake Zurich, } \\
\text { Illionis, USA }\end{array}$ \\
\hline $\mathrm{K}-2$ & Everest Bio ZS & Pre-sintered & $\begin{array}{l}\text { KaVo Dental, } \\
\text { Lake Zurich, } \\
\text { Illionis, USA }\end{array}$ \\
\hline
\end{tabular}

Table 1. The codes, brands, sinterization process and manufactures of the ceramics used for the experiments. Sintering process of $\mathrm{L}-2, \mathrm{C}-2, \mathrm{I}-2$, and $\mathrm{K}-2$ brands were performed according to manufacturer recommendations at $1500^{\circ} \mathrm{C} / 11 \mathrm{~h}, 1350^{\circ} \mathrm{C} / 6 \mathrm{~h}, 1500^{\circ} \mathrm{C} / 5 \mathrm{~h}$, and $1450^{\circ} \mathrm{C} / 10 \mathrm{~h}$, respectively. 


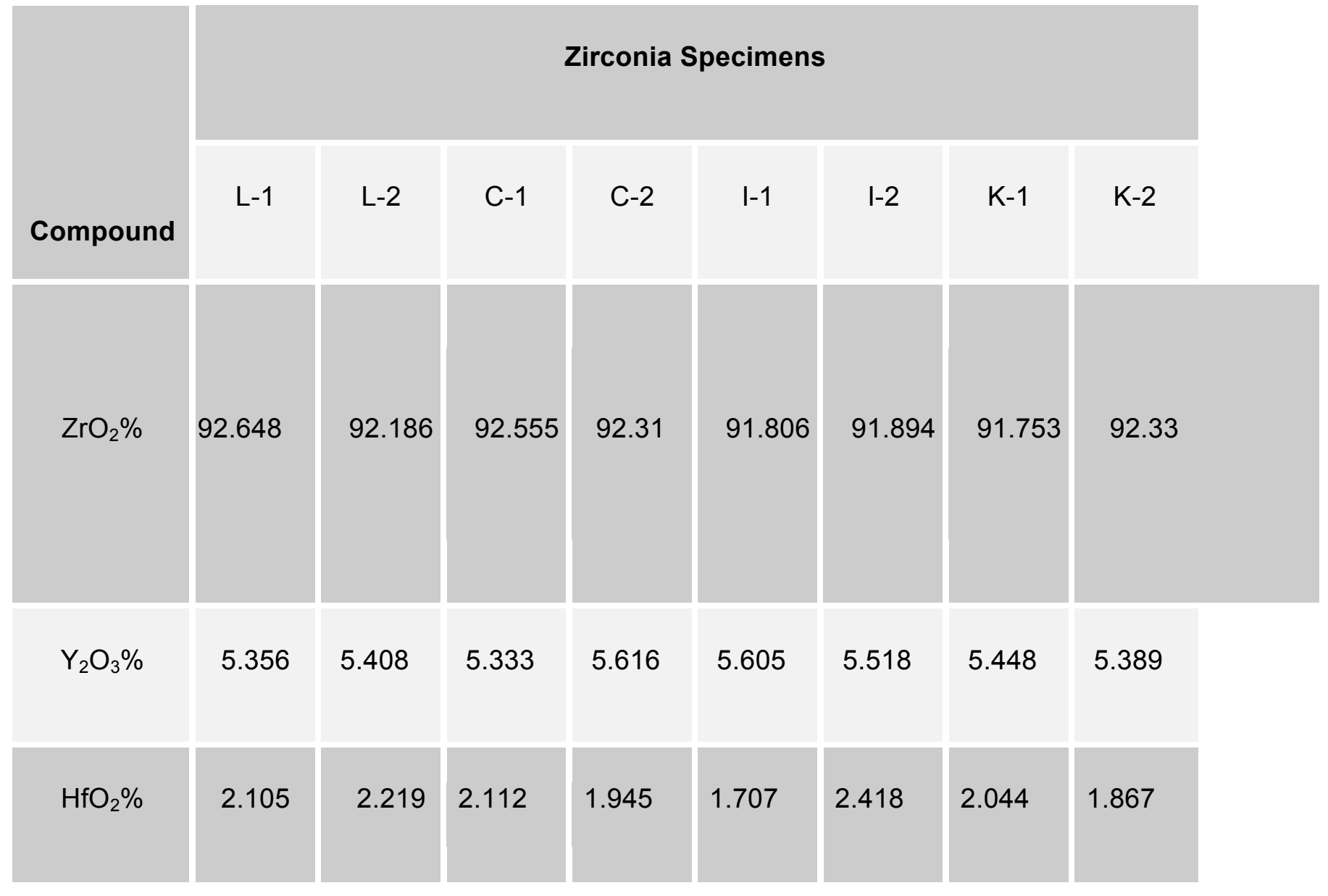

Table 2. XRF analyses of all the zirconia specimens and percentages of the major compounds. These analyses were performed to investigate the degradation of the major compounds which were higher $0.5 \%$ of total composition. Ratios of the compounds of specimens in presintered and sintered forms did not show significant alteration. 


\section{Figures}

Figs. 1a-b. Representative X-Ray Fluorescence Spectrometer (XRF) analysis for the $\mathrm{Zr}$ and $\mathrm{Hf}$ elements of Everest Bio ZS $\mathrm{ZrO}_{2}$ ceramic specimen in a) presintered b) sintered form. The peaks are the characteristic X-rays of the elements in the specimens. X-axis shows the energy levels. According to graphics there is no significant difference between two forms. In all groups and all forms no difference was detected where $\mathrm{K}-1$ and $\mathrm{K}-2$ specimens were randomly selected to evaluate their energy levels.
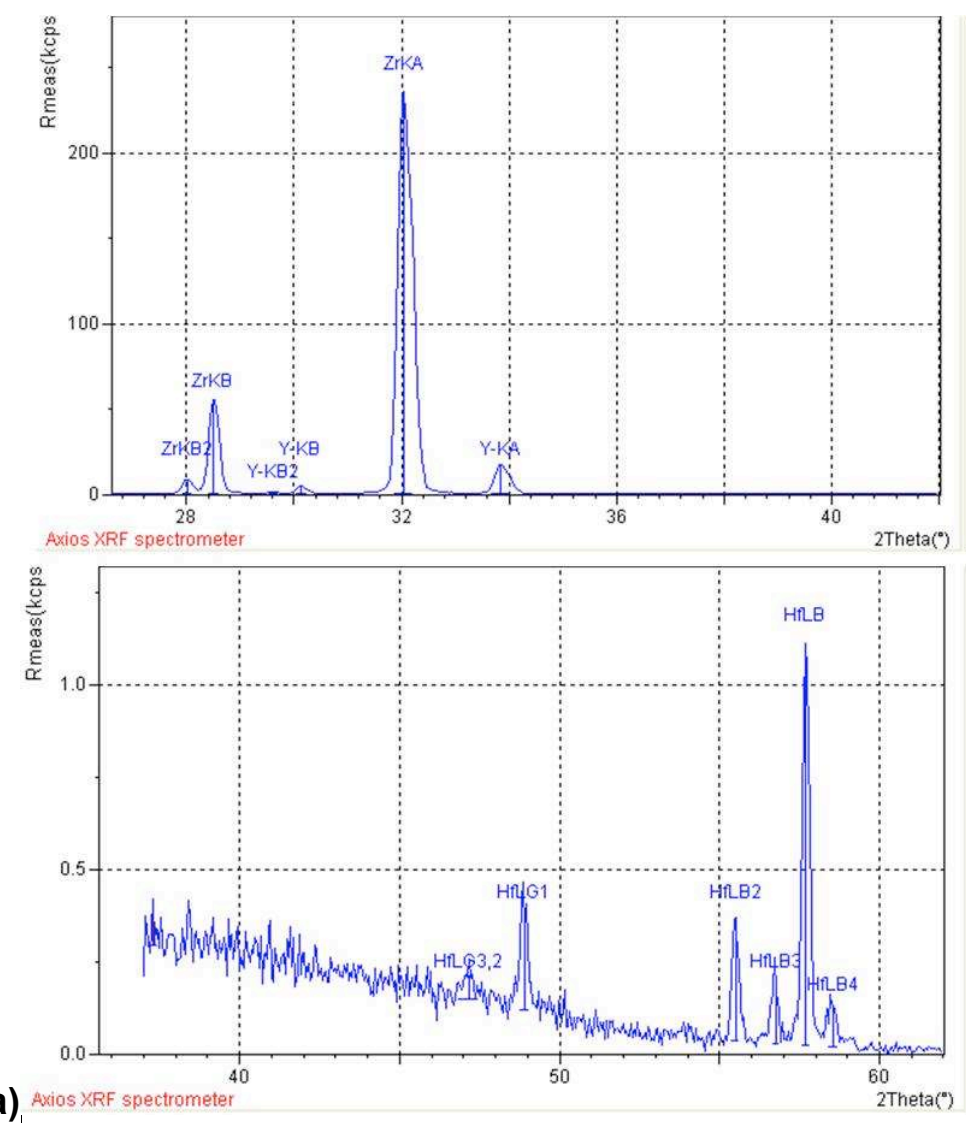


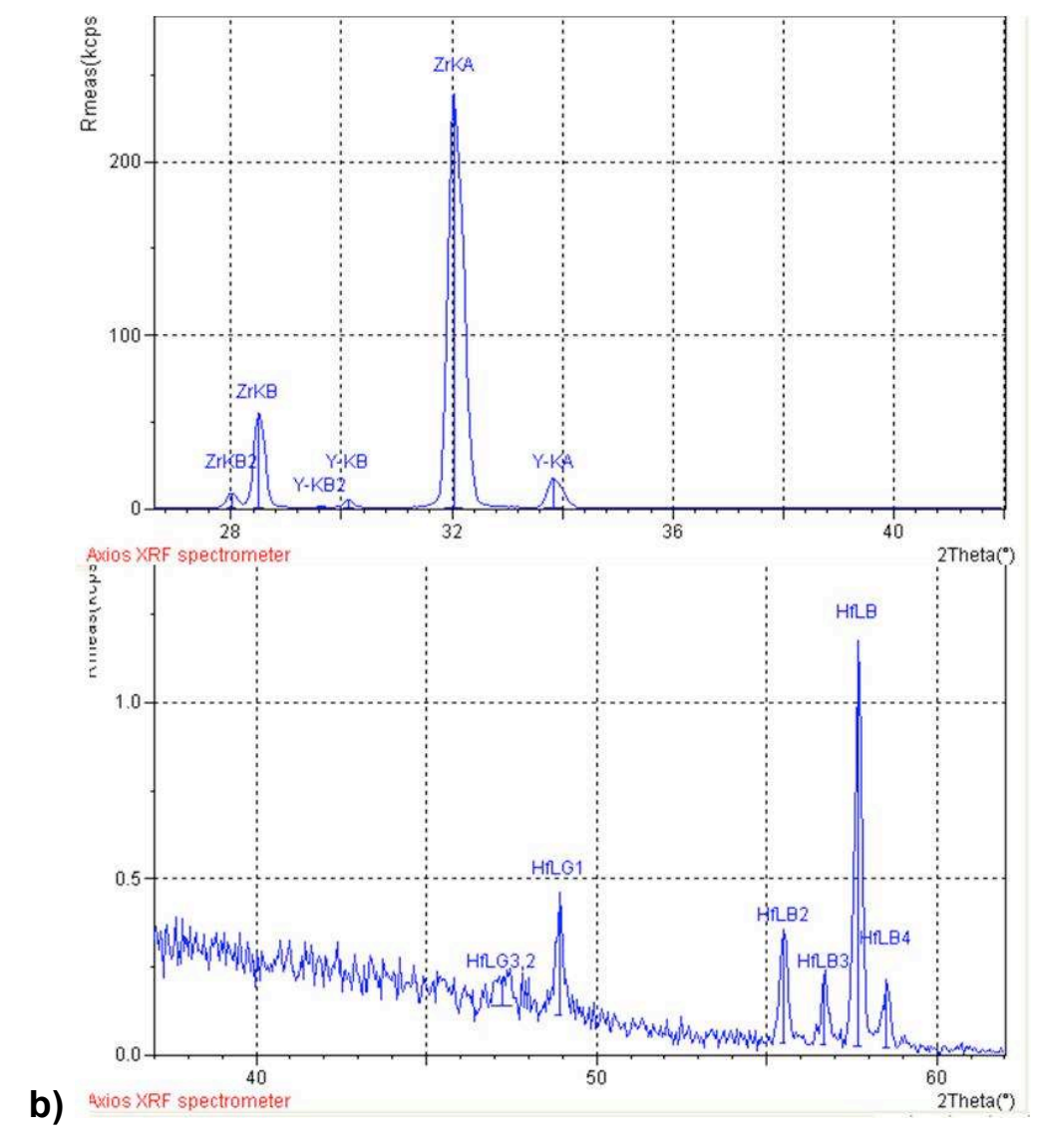

